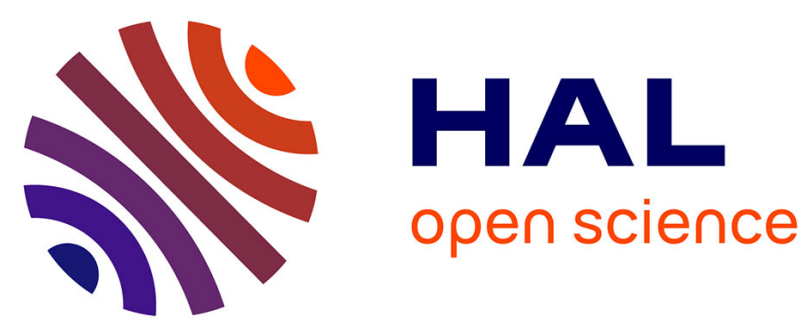

\title{
Medicinal \& Aromatic Plants First Phytochemical Characterization and Essential Oil Analysis of the Traditional Catalan Wild Salad: "Coscoll " (Molopospermum peloponnesiacum (L.) Koch)
} Vanessa Andreu, Audrey Amiot, M Safont, A Levert, C Bertrand

\section{To cite this version:}

Vanessa Andreu, Audrey Amiot, M Safont, A Levert, C Bertrand. Medicinal \& Aromatic Plants First Phytochemical Characterization and Essential Oil Analysis of the Traditional Catalan Wild Salad: " Coscoll " (Molopospermum peloponnesiacum (L.) Koch). Medicinal and aromatic plants, 2015, 4 (4), 10.4172/2167-0412.1000211. hal-01250704

\section{HAL Id: hal-01250704 \\ https://hal-univ-perp.archives-ouvertes.fr/hal-01250704}

Submitted on 5 Jan 2016

HAL is a multi-disciplinary open access archive for the deposit and dissemination of scientific research documents, whether they are published or not. The documents may come from teaching and research institutions in France or abroad, or from public or private research centers.
L'archive ouverte pluridisciplinaire HAL, est destinée au dépôt et à la diffusion de documents scientifiques de niveau recherche, publiés ou non, émanant des établissements d'enseignement et de recherche français ou étrangers, des laboratoires publics ou privés. 


\title{
First Phytochemical Characterization and Essential Oil Analysis of the Traditional Catalan Wild Salad: "Coscoll” (Molopospermum peloponnesiacum (L.) Koch)
}

Andreu $\mathbf{V}^{1,2 *}$, Amiot $A^{2}$, Safont $M^{1}$, Levert $A^{2}$ and Bertrand $C^{1,2}$

${ }^{1}$ Centre de Recherches Insulaires et Observatoire de l'Environnement, USR 3278, University of Perpignan Via Domitia, Perpignan, France ${ }^{2}$ AkiNaO, Perpignan, France

\begin{abstract}
"Coscoll"(Molopospermum peloponnesiacum (L.) Koch) whose stems are traditionally consumed raw in salads in Catalonia is associated in oral tradition with many virtues as digestive, purifying, exciting, antioxidant and hematocathartic activities. However, stem composition and biological activity had never been studied. Nutritive values of plant material were determined by official methods and constituents from essential oil of Molopospermum peloponnesiacum stems were characterized for the first time in this study. The main constituents were dillapiol $(60.1 \%)$ and 3-carene (15.2\%). Moreover, total polyphenol content using Folin-Ciocalteu method, and 2,2-diphenyl-1-picrylhydrazyl (DPPH) free radical scavenging activity were determined. Molopospermum peloponnesiacum stem total polyphenol content was $101.0 \pm 10.0 \mathrm{mg} / 100 \mathrm{~g}$ fresh weight (Gallic Acid Equivalent) and DPPH radical scavenging activity, relatively high, was close from spinach one. Thus, these first results reveal the potential beneficial properties of this plant, in relation with its traditional use in Catalonia.
\end{abstract}

Keywords: Molopospermum peloponnesiacum stems; Nutritive values; Essential oil analysis; Total polyphenol content; DPPH radical scavenging activity

\section{Introduction}

Molopospermum peloponnesiacum (L.) Koch is a perennial plant endemic to mountainous area of Southern Alps and Pyrenees. Molopospermum is a monotypic genus belonging to the Apiaceae family and Apioideae subfamily. Its phylogenetic classification is not clearly defined [1-3] but most recent phylogenetic study based on chloroplast genome trnQ-trnK region analysis seems to integrate Molopospermum into the clade of Annesorhizeae [4].

In Pyrenees, where the plant is also name "Coscoll" in Catalan language, $M$. peloponnesiacum young shoots are traditionally eaten raw in salads. Oral tradition extols many virtues of coscoll, as digestive, purifying, and exciting activities. It has been collected throughout generations in this country and cures are traditionally made from coscoll for its hematocathartic properties [5].

M. peloponnesiacum contains a large amount of volatile compounds and gives off a strong odor. Root and fruit essential oil have been identified in literature, containing mainly 3 -carene, trimethylbenzoic acids, and dillapiol as major compounds [6-7]. However, to our knowledge, stem composition or biological activity had never been characterized. This paper thus deals with the chemical characterization of stems. We described nutritive characterization and essential oil analysis. In addition, we determined stem polyphenol content and 2,2-diphenyl-1-picrylhydrazyl (DPPH) radical scavenging activity in order to identify potential beneficial properties in this plant material traditionally consumed.

\section{Materials and Methods}

\section{Plant material}

Plant material was collected in May 2011 in Mantet Col (PyrénéesOrientales, France) during inflorescence emergence stage, as stems are traditionally consumed. All plants specimen were 3-4 years old and were identified by Cédric Bertrand based on morphological description.
A voucher specimen was deposited at the Herbarium of the University Claude Bernard Lyon1, city of Villeurbanne, France, under the name "Collection Piola" and collector number 4.

An aliquot was dried and conserved for phytochemical analysis. Dry mass stems was $15 \% \mathrm{w}$ :w.

\section{Global characterization of $\mathrm{pl}^{\mathrm{Tw}}$ ant material}

Protein dosage was determined according to the AOAC Official Method 984.13 [8]. Lipid amount was determined using the ISO 1443 method [9] and lipid profile was analyzed according to the AOCS Ce 1h-05 method [10]. Soluble sugar content was determined after oximation and silylation then analyzed by gas chromatography with a $30 \mathrm{~m}$ SIL5CB column coupled with FID detection, using xylitol as internal standard. Mineral amount was evaluated according to the AOAC Official Method 923.03 [11]. Fiber dosage was determined according to the AOAC Official Method 985.29 [12]. Energetic values were calculated according European regulation 1169/2011 [13]. All essays were done on a mix of stems from six different plants.

\section{Essential oil distillation}

$100 \mathrm{~g}$ of fresh stem parts from six Molopospermum peloponnesiacum specimen from the same mountain area were directly subjected to hydrodistillation for $2 \mathrm{~h}$. Volatile oil was collected by extraction using

*Corresponding author: Vanessa Andreu, Centre de Recherches Insulaires et Observatoire de l'Environnement, USR 3278, University of Perpignan Via Domitia, 66860 Perpignan, France, Tel: +33-468-662-073; E-mail: vanessa.andreu@univ-perp.fr

Received September 14, 2015; Accepted September 25, 2015; Published September 28, 2015

Citation: Andreu V, Amiot A, Safont M, Levert A, Bertrand C (2015) First Phytochemical Characterization and Essential Oil Analysis of the Traditional Catalan Wild Salad: "Coscoll" (Molopospermum peloponnesiacum (L.) Koch). Med Aromat Plants 4: 211. doi:10.4172/2167-0412.1000211

Copyright: $\odot 2015$ Andreu V, , et al. This is an open-access article distributed unde the terms of the Creative Commons Attribution License, which permits unrestricted use, distribution, and reproduction in any medium, provided the original author and source are credited. 
Citation: Andreu V, Amiot A, Safont M, Levert A, Bertrand C (2015) First Phytochemical Characterization and Essential Oil Analysis of the Traditional Catalan Wild Salad: "Coscoll" (Molopospermum peloponnesiacum (L.) Koch). Med Aromat Plants 4: 211. doi:10.4172/2167-0412.1000211

Page 2 of 4

heptane and aqueous phase was separated with anhydrous sodium sulfate. Extracted oils were stored in glass vessels at $-20^{\circ} \mathrm{C}$ and protected from light. Essential oil extraction yield was $0.047 \% \mathrm{w}: \mathrm{w}$ fresh stems.

\section{GC-FID and GC-MS analysis of the essential oil}

Essential oil components were identified using gas chromatography with Thermo Scientific Focus GC system coupled with DSQ II system mass detector. Analysis was realized with a HP-5MS column $(30 \mathrm{~m} \times$ $0.25 \mathrm{~mm}$ i.d. $\times 0.25 \mu \mathrm{m}, 5 \%$-phenyl-arylene-95\%-dimethylpolysiloxan, Phenomenex, Torrance, California, US). Column head flow was set at $1 \mathrm{ml} / \mathrm{min}$, using helium as carrier gas. Column temperature was programmed as follows: $80^{\circ} \mathrm{C}$ for $3 \mathrm{~min}, 80^{\circ} \mathrm{C}$ to $110^{\circ} \mathrm{C}\left(2^{\circ} \mathrm{C} / \mathrm{min}\right)$, $110^{\circ} \mathrm{C}$ to $240^{\circ} \mathrm{C}\left(5^{\circ} \mathrm{C} / \mathrm{min}\right), 240^{\circ} \mathrm{C}$ to $290^{\circ} \mathrm{C}\left(10^{\circ} \mathrm{C} / \mathrm{min}\right)$ and $290^{\circ} \mathrm{C}$ for 3 minutes. Total run time was $52 \mathrm{~min}$.

Injector temperature was maintained at $280^{\circ} \mathrm{C}$, and injection volume was $1.0 \mu \mathrm{L}$ in split mode with a $10 \mathrm{ml} / \mathrm{min}$ split flow. Transfer line temperature was $300^{\circ} \mathrm{C}$. Electron multiplier voltage was set to $1330 \mathrm{~V}$ by automatic tuning. Mass spectra were recorded at $70 \mathrm{eV}$ with the mass range at 50-650. Linear retention indices were calculated for all constituents using homologous series of $n$-alkanes (Alkane solution $\mathrm{C}_{8}-\mathrm{C}_{20}$, Fluka, Buchs, Switzerland). Essential oil constituents were identified through mass spectra studies and were confirmed by comparing retention indices with those reported in literature [14-18].

Major compounds were quantified using gas chromatography with a Thermo Scientific Focus GC and flame ionization detector with the same conditions described previously. The relative quantification of the components was performed by comparison of their peak area. Mean and standard deviation were calculated on the basis of replicate from six different plants.

\section{Preparation of alcoholic extract}

$50 \mathrm{~g}$ of dry stems were extracted three times with $500 \mathrm{ml}$ of ethanol for 15 minutes in an ultrasonic bath, then filtered and dried under vacuum. Extraction yield was $11.4 \%$ (w:w dry stems).

\section{Determination of total polyphenol contents}

Total polyphenol content was determined by Folin-Ciocalteu phenol method as described by Singleton et al. [19] with some modifications. $175 \mu \mathrm{l}$ of appropriately diluted sample or gallic acid standard were added to $25 \mu \mathrm{l}$ of Folin-Ciocalteu phenol reagent and $50 \mu \mathrm{l}$ of $20 \%$ (w/v) $\mathrm{Na}_{2} \mathrm{CO}_{3}$ solution and mixed. After incubation for 30 minutes at room temperature, absorbance was measured at $725 \mathrm{~nm}$ versus a prepared blank containing solvent instead of gallic acid or sample. The calibration equation for gallic acid was $\mathrm{y}=0,0395 \times+0.0008$ $\left(\mathrm{R}^{2}=0.9993\right)$.

Total phenolic content was expressed as mg gallic acid equivalent (GAE)/100 g of fresh plant. Mean and standard deviation $(\mathrm{n}=3)$ were calculated.

Folin reagent and gallic acid were purchased from Sigma-Aldrich (Saint-Louis, Missouri, USA).

\section{Determination of DPPH radical scavenging activity}

M. peloponnesiacum stems ethanolic extract free radical scavenging activity was determined in 96-well microplates using the DPPH method [20] with some modifications. $20 \mu \mathrm{l}$ ethanol solution containing a different concentration of $M$. peloponnesiacum stems extract was added to $200 \mu \mathrm{l}$ of freshly prepared 2,2-diphenyl-1-picrylhydrazyl methanol solution $(0,2 \mathrm{mM})$ (Sigma-Aldrich, Saint-Louis, Missouri, United
States). Ethanol was used as the control. After 60 minutes of incubation at room temperature in the dark, absorbance was measured at $515 \mathrm{~nm}$ using a microplate reader Aviso, Sirius HT (Ebersberg, Germany). Vitamin-C was used as standard (Supelco, Bellefonte, Pennsylvania, US).

Standard curves for assay was obtained by measuring the DPPH scavenging activity of 1, 5, 10, 25, $50 \mathrm{mg}$ vitamin C/L. DPPH scavenging activity was expressed as mg vitamin C equivalent (VCE)/100 $\mathrm{g}$ of fresh plant. Mean and standard deviation $(n=3)$ were calculated.

\section{Results and Discussions}

\section{Global characterization of Molopospermum peloponnesia-} cum stems

Content of soluble sugars, fibers, protein, ashes and lipids in fresh and dried stems are presented in Table 1. Soluble sugars, fibers and protein values were particularly high in Molopospermum peloponnesiacum stems whereas lipid amount was very low.

\section{Essential oil analysis}

The essential oil composition is listed in Table 2. Main compounds identified in stem essential oil were dillapiol ( $60 \%$ relative content) and 3 -carene ( $15 \%$ relative content). Stem essential oil composition was very close to the root essential oil composition determined in literature for dillapiol chemotype [7]. Dillapiol is a well-known phenylpropanoid, extracted from essential oils of several plants as matico (Piper aduncum), parsley (Petroselinum crispum), pepper elder (Peperomia pellucida) or dill (Anethum graveolens) [21-24]. This compound presents in vitro antieishmanial, gastropotective and anti-inflammatories activities [21-23]. Its structure, close to phenylisopropylamine structures could suggest a possible psychotropic activity as tonic or exciting [25].

\section{Determination of total polyphenol content and DPPH radi- cal scavenging activity}

Total polyphenol content and 2,2-diphenyl-1-picrylhydrazyl radical scavenging activity of $M$. peloponnesiacum stems are shown in Table 3. Total polyphenol content determined for the peloponnesiacum stems expressed in Gallic Acid Equivalent (GAE) was $101.0 \pm 10.0 \mathrm{mg}$ GAE/100 g fresh weight. DPPH radical scavenging capacity expressed in vitamin $\mathrm{C}$ equivalent (VCE) was $77.7 \pm 5.59 \mathrm{mg} \mathrm{VCE} / 100 \mathrm{FW} . M$. peloponnesiacum stem has relatively strong DPPH radical scavenging

\begin{tabular}{|c|c|c|}
\hline Analyse & Unit & Value* \\
\hline Water & $g / 100 g$ FW & 85 \\
\hline Soluble sugar & g/100g FW (g/100g DW) & $5.56(37.0)$ \\
\hline including simple sugar & g/100g FW (g/100g DW) & $3.46(23.1)$ \\
\hline Fiber & g/100g FW (g/100g DW) & $4.66(31.1)$ \\
\hline Protein & g/100g FW (g/100g DW) & $3.28(21.9)$ \\
\hline Ashe & g/100g FW (g/100g DW) & $1.46(9.7)$ \\
\hline including sodium & mg/100g FW (mg/100g DW) & $3.9(26)$ \\
\hline Lipid & g/100g FW (g/100g DW) & $0.04(0,3)$ \\
\hline FA saturated & g/100g FW (g/100g DW) & $0.02(0.1)$ \\
\hline FA monsaturated & g/100g FW (g/100g DW) & $0.00(0.00)$ \\
\hline FA polysaturated & g/100g FW (g/100g DW) & $0.03(0.2)$ \\
\hline Energetic value & $\begin{array}{c}\text { Kcal/100g FW (Kcal/100g DW) } \\
\text { KJ/100g FW (KJ/100g DW) }\end{array}$ & $\begin{array}{c}45(300) 188 \\
(1255)\end{array}$ \\
\hline
\end{tabular}

FA : Fatty acids ; FW : fresh weight ; DW : Dry weight

* Values were obtained according official dosage methods; essays were done on a mix of stem from six different plants

Table1: Nutritive composition of Molopospermum peloponnesiacum stems. 
Citation: Andreu V, Amiot A, Safont M, Levert A, Bertrand C (2015) First Phytochemical Characterization and Essential Oil Analysis of the Traditional Catalan Wild Salad: "Coscoll" (Molopospermum peloponnesiacum (L.) Koch). Med Aromat Plants 4: 211. doi:10.4172/2167-0412.1000211

\begin{tabular}{|c|c|c|c|c|c|c|}
\hline $\mathbf{N}^{\circ}$ & RI & RI ref & Ref & Compound & $\begin{array}{c}\text { Relative content } \\
(\%)^{*}\end{array}$ & $\mathrm{mg} / 100 \mathrm{~g} \mathrm{FW}$ \\
\hline 1 & 937 & 939 & [14] & a-pinene & $2.77+/-1.16$ & $.29+/-0.54$ \\
\hline 2 & 975 & 975 & [14] & Sabinene & $.14+/-0.03$ & $.06+/-0.01$ \\
\hline 3 & 984 & 979 & [14] & $\beta$-pinene & $0.92+/-0.35$ & $0.43+/-0.16$ \\
\hline 4 & 990 & 991 & [14] & Myrce & $.56+/-0.17$ & $.26+/-0.08$ \\
\hline 5 & 1016 & 1011 & [14] & 3-car & $5.22+/-4.18$ & 1.94 \\
\hline 6 & 1026 & 1027 & [15] & cymene & $35+/-c$ & $16+/-0.02$ \\
\hline 7 & 1034 & 1029 & [14] & limonene & $68+/-0.85$ & $.71+/-0.4$ \\
\hline 8 & 1058 & 1060 & [14] & $\mathrm{Y}$ - terpinen & $.57+/-0.16$ & $0.26+/-0.08$ \\
\hline 9 & 1089 & 1089 & [14] & terpinol & $38+/-0.03$ & $0.17+/-0.01$ \\
\hline 10 & 1101 & 1097 & [14] & $\alpha$ - linalool & $0.29+/-0$ & $0.13+/-0$ \\
\hline 11 & 1131 & 1129 & [14] & allo-ocimene & $0.07+1$ & $.03+/-0$ \\
\hline 12 & 1230 & 1226 & [14] & citronellol & $39+/-0.17$ & $.18+/-0.08$ \\
\hline 13 & 1237 & 1236 & [16] & 2-Nonyl acetate & $0.215+/-0.025$ & 0.01 \\
\hline 14 & 1337 & 1338 & [14] & $\delta$ - elemene & $1+/-0.45$ & $0.46+/-0.21$ \\
\hline 15 & 1352 & 1353 & [14] & citronellyl acetate & $0.78+/-0.16$ & $36 /-0.08$ \\
\hline 16 & 1422 & 1419 & [14] & trans-caryophyllene & $19+/-c$ & $55+/-0.3$ \\
\hline 17 & 1459 & 1455 & [14] & a-humulene & $83+/-(-1-2-1$ & $0.38+/-0.11$ \\
\hline 18 & 1484 & 1485 & [14] & D-germacrene & $1.86+/-0.85$ & $0.86+/-0.4$ \\
\hline 19 & 1498 & 1500 & [14] & bicyclogermacrene & $0.9+/-0.1$ & $0.42+/-0.05$ \\
\hline 20 & 1562 & 1563 & [14] & trans-nerolidol & $0.31+/-0$ & $0.14+/-0$ \\
\hline 21 & 1623 & 1621 & [14] & dillapiol & $60.12+/-8.04$ & $28.04+/-3.75$ \\
\hline 22 & 1667 & 1654 & [14] & $\alpha$-cadi & $29+1-0$ & $0.13+/-0.04$ \\
\hline 23 & 1683 & 1676 & {$[17$} & tradecanol-1 & $2.72+/-0.09$ & $1.27+/-0.04$ \\
\hline 24 & 1769 & ND & ND & $\mathrm{m} / \mathrm{z} 252$ & $1.62+0.33$ & $0.75+/-0.15$ \\
\hline 25 & 1882 & 1883 & [18] & 1-hexadecenol & $1.19+/-0.31$ & $0.55+/-0.14$ \\
\hline
\end{tabular}

Total monoterpenes $27.33 \% 12.7 \mathrm{mg} / 100 \mathrm{~g}$ stems

Total sesquiterpenes $5.09 \% 2.3 \mathrm{mg} / 100 \mathrm{~g}$ stems

Total other compounds $64.32 \% 29.9 \mathrm{mg} / 100 \mathrm{~g}$ stems

Total identified $96.74 \% 44.9 \mathrm{mg} / 100 \mathrm{~g}$ stems

$\mathrm{RI}$ : Retention indices calculated with $\mathrm{n}$-alkanes. Percentage are calculated from FID data..

RI ref : Retention indices from literature.

ND : Not determined.

FW : fresh weight.

* Data are the mean values of six replicates

Table 2: Composition of Molopospermum peloponnesiacum stem essential oil.

\begin{tabular}{|c|c|}
\hline Total Polyphenol Content $^{*}$ & DPPH radical scavenging capacity* \\
\hline mg GAE.100 ${ }^{-1} \mathrm{FW}$ & $\mathrm{mg} \mathrm{VCE} / 100 \mathrm{~g} \mathrm{FW}$ \\
\hline $101.0 \pm 10.0$ & $77.7 \pm 5.59$ \\
\hline
\end{tabular}

GAE : Gallic Acid Equivalent ; FW: Fresh Weight ; VCE : Vitamin C Equivalent. *Data are the mean value of three replicates

Table 3: Total polyphenol content (TPC) and DPPH free-radical scavenging capacity of Molopospermum peloponnesiacum fresh stems.

capacity. For comparison, this result is close to that obtained in literature for spinach $(71 \mathrm{mg} \mathrm{VCE} / 100 \mathrm{FW})$ and nearly twice that of lettuce (43 mg VCE/100 FW) [26].

\section{Conclusion}

In this study, Molopospermum peloponnesiacum stems composition was characterized for the first time. We looked at its nutritive values and antioxidant capacity. Our results indicate a large amount of soluble sugars, fibers and protein in the stems and an essential oil containing dillapiol and 3-carene as major compounds, similar to that described previously for root essential oil. This first study permitted to chemically characterize this part of the plant that is traditionally consumed and to get a better idea of its potential beneficial properties.

\section{Acknowledgements}

The authors of this study are very thankful to Daniel Aspe for his help in plant collection and for sharing his knowledge on "coscoll". The spectroscopic experiments have been performed using the "Biodiversité et Biotechnologies Marines" (Bio2Mar) facilities at the University of Perpignan.

\section{References}

1. Liu MR, Plunkett GM, Lowry PP, Van Wyk BE, Tilney PM (2006) The taxonomic value of fruit wing types in the order Apiales. Ame J Bot 93: 1357-1368.

2. Calviño Cl, Tilney PM, Van Wyk BE, Downie SR (2006) A molecular phylogenetic study of southern African Apiaceae. Am J Bot 93: 1828-1847.

3. Magee AR, Van Wyk BE, Tilney PM, Downie SR (2008) Ezosciadium (Apiaceae): a taxonomic revision of yet another early diverging South African apioid genus. Plant Syst Evol 276: 167-175.

4. Magee AR, Calviño Cl, Liu M, Downie SR, Tilney PM, et al. (2010) New tribal delimitations for the early diverging lineages of Apiaceae subfamily Apioideae. Taxon 59: 567-580.

5. Parada M, Carrio E, Vallès J (2011) Ethnobotany of food plants in the Alt emporda region (Catalonia, Iberian Peninsula). J Appl Bot Food Qual 84: 1125.

6. Kubeczka KH, Ullmann I (1981) Terpenoids of the essential oil from Molopospermum peloponnesiacum roots. Phytochem 20: 828-830.

7. Kubeczka KH, Ullman I (1983) Chemotypes of Molopospermum peloponnesiacum (L.) Koch. Z Naturforsch 38c: 189-193.

8. Association Of Analytic Chemistry (2005) AOAC Official Method 984.13 (A-D) $\left(18^{\text {th }}\right.$ edn), Official Methods of Analysis of AOAC international, Gaithersburg Maryland, US.

9. International Organization For Standardization (1973) ISO 1443. Meat and meat products. Determination of total fat content. International organization for standardization, Geneva, Swiss

10. American Oil Chemists Society (2005) Official method Ce $1 \mathrm{~h}-05$. (6 ${ }^{\text {th }}$ edn) Official methods and recommended practices of the AOCS, Champaign, Illinois, US.

11. 11. Association of Analytic Chemistry (2005) AOAC Official Method 923.03 (AD). $\left(18^{\text {th }}\right.$ edn), Official Methods of Analysis of AOAC international, Gaithersburg Maryland, US

12. Association of Analytic Chemistry (2005) AOAC Official Method 985.29 (A-D) Official. (18 $8^{\text {th }}$ edn), Methods of Analysis of AOAC international, Gaithersburg Maryland, US.

13. Règlement Européen (2011) Règlement (UE) no 1169/2011 du parlement européen et du conseil du 25 octobre 2011 concernant l'information des consommateurs sur les denrées alimentaires. Journal Officiel de I'Union Européenne L304: 18 - 63

14. Adams RP (2001) Identification of essential oil components by gas chromatography/quadrupole mass spectroscopy. ( $3^{\text {rd }}$ ed), Allured Publishing Corporation Carol Stream, Illinois, US.

15. Maxia A, Falconieri D, Piras P, Porcedda S, Marongiu B, et al. (2012) Chemica composition and antifungal activity of essential oils and supercritical $\mathrm{CO} 2$ extracts of Apium nodiflorum (L.) Lag. Mycopathologia 174: 61-67.

16. National Institute Of Standars And Technology (2004) Retention Data, NIST Mass Spectrometry Data Center. Gaithersburg, Maryland, US.

17. Saroglou V, Dorizas N, Kypriotakis Z, Skaltsa HD (2006) Analysis of the essential oil composition of eight Anthemis species from Greece. J Chrom A 1104: 313-322.

18. Hazzit M, Baaliouamer A, Faleiro ML, Miguel MG (2006) Composition of the essential oils of Thymus and Origanum species from Algeria and their antioxidant and antimicrobial activities. J Agri Food Chem 54: 6314-6321.

19. Singleton VL, Rossi JA (1965) Colorimetry of total phenolics with phosphomolybdicphosphotungistic acid reagents. Ame J Enol Vitic 16: 144-158.

20. Brand Williams W, Cuvelier ME, Berset C (1995) Use of a free radical method to evaluate antioxidant activity. LWT - Food Sci Technol 28: 25-30.

21. Parise Filho R, Pastrello M, Pereira Camerlingo CE, Silva GJ, Agostinho LA et al. (2011) The anti-inflammatory activity of dillapiole and some semisynthetic analogues. Pharm Biol 49: 1173-1179.

22. Parise-Filho R, Pasqualoto KF, Magri FM, Ferreira AK, Da Silva BA, et al 
Citation: Andreu V, Amiot A, Safont M, Levert A, Bertrand C (2015) First Phytochemical Characterization and Essential Oil Analysis of the Traditional Catalan Wild Salad: "Coscoll" (Molopospermum peloponnesiacum (L.) Koch). Med Aromat Plants 4: 211. doi:10.4172/2167-0412.1000211

(2012) Dillapiole as antileishmanial agent: discovery, cytotoxic activity and preliminary SAR studies of dillapiole analogues. Arch Pharm (Weinheim) 345 934-944

23. Rojas Martínez R, Arrieta J, Cruz Antonio L, Arrieta Baez D, VelázquezMéndez AM, et al. (2013) Dillapiole, isolated from Peperomia pellucida, shows gastroprotector activity against ethanol-induced gastric lesions in Wistar rats. Molecules 18: 11327-11337.

24. Lamarti A, Badoc A, Deffieux G, Carde JP (1993) Etude des arylpropènes extraits de l'huile essentielle des fruits de Persil [petroselinum crispum (mill.) A W. Hill]. Bull Soc Pharm Bordeaux 132: 90-98

25. Shulgin AT (1967) Psychotropic phenylisopropylamines derived from apiole and dillapiole. Nature 215: 1494-1495.

26. Floegel A, Kim DO, Chung SJ, Koo SI, Chun OK (2011) Comparison of ABTS $\mathrm{DPPH}$ assays to measure antioxidant capacity in popular antioxidant-rich US foods. J Food Compos Anal 24: 1043-1048.
OMICS International: Publication Benefits \& Features Unique features:

- Increased global visibility of articles through worldwide distribution and indexing

Showcasing recent research output in a timely and updated manner

Special issues on the current trends of scientific research

Special features:

- 700 Open Access Journals

50,000 Editorial team

Rapid review process

Quality and quick editorial, review and publication processing

Indexing at PubMed (partial), Scopus, EBSCO, Index Copernicus, Google Scholar etc.

Sharing Option: Social Networking Enabled

- Sharing Option: Social Networking Enabled

Buthors, Reviewers and Editors rewarded wiscount for your subsequent articles

Submit your manuscript at: http://www.omicsonline.org/submission 